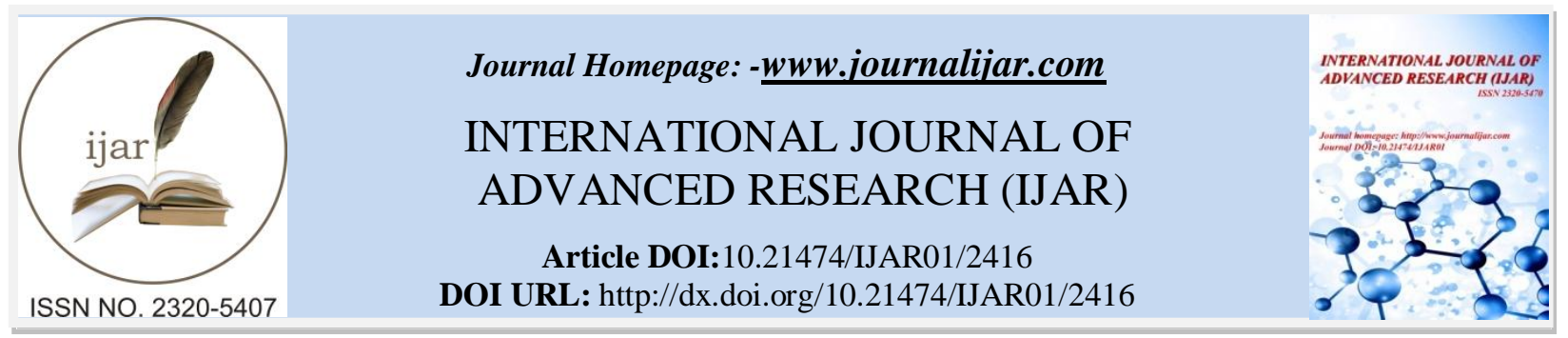

RESEARCH ARTICLE

\title{
PARTIAL PURIFICATION AND CHARACTERISATION OF L-ASPARAGINASE FROM GORDONIA SP KM067296 ISOLATED FROM LONAR LAKE (MAHARASHTRA.INDIA).
}

Ganjave Snehal, Bhat Manish and Marar Thankamani*.

School of Biotechnology and Bioinformatics, D.Y. Patil University, CBD Belapur, Navi Mumbai, Pin-400614, Maharashtra, India.

\section{Manuscript Info}

Manuscript History

Received: 20 October 2016

Final Accepted: 22 November 2016

Published: December 2016

Key words:-

L-asparagine amino hydrolase, halotolerant, Gordonia terrae, Purification, anti-leukemic.

\section{Abstract}

A unique extracellular L-Asparaginase or L-asparagine amino hydrolase (E.C.3.5.1.1) was studied as a potent anti-leukemic candidate. Lonar lake provides an extraordinary environment for halotolerant and alkali tolerant microbes. Many researches have been carried out on its microbial flora but the study on L-asparaginase producing species have not been reported very extensively and an attempt for the same is made in this study. In the present study new potential bacterial L-asparaginase producer Gordonia terrae KM067296 has been studied for enzyme production and partial purification and characterization of the enzyme was also carried out. The crude enzyme extract was partially purified using ammonium sulfate precipitation, dialysis, and gel filtration. The partially purified L-asparaginase showed specific activity of $38.61 \mathrm{IU} / \mathrm{mg}$ and was purified up to 14 fold post gel filtration and showed maximal activity against $\mathrm{L}$-asparagine when incubated at $\mathrm{pH} 7.4$ at $37^{\circ} \mathrm{C}$ for 30 minutes with substrate concentration of $0.04 \mathrm{M}$. The activity of L-asparaginase was enhanced by $\mathrm{MgCl}_{2}$ and was inhibited by EDTA. The molecular weight of the enzyme was found to be approximately $12 \mathrm{kDa}$. A Line weaver Burk analysis showed a $\mathrm{Km}$ value of $0.061 \mathrm{mM}$ and Vmax of 0.57 IU. This study revealed Gordonia terrae KM067296 as a prospective source for high yielding and highly substrate specific production of $\mathrm{L}$-asparaginase.

Copy Right, IJAR, 2016, All rights reserved.

\section{Introduction:-}

L-Asparaginase (L-asparagine amino hydrolase, EC 3.5.1.1) represents one of the most biotechnologically and biomedically important class of therapeutic enzymes contributing for about $40 \%$ of the total worldwide enzyme sales (Eishafei et al., 2012). L-asparaginase, an amidase hydrolyses the amide bond in L-asparagine to give aspartic acid \& ammonia (Aljewari et al., 2010) and play vital role in the metabolism of all living organisms (Anese M, 2011). It keeps nitrogen balance and the level of amino acids within cells. L-asparaginase has been broadly studied in plants, animals, rodents and microorganisms of which the most commonly utilized microorganisms for Lasparaginase production are Erwinia caratovora, Bacillus spp., Cornybacterium glutamicum, Aspergillus terreus, Withania somnifera and E.coli(Kumar and Verma, 2012)however tumour inhibitory activity of L-asparaginase has been reported with E.coli, Erwinia aroideae andSerratia marcescens that have reached up to clinical trials. Chronic

Corresponding Author: -Marar Thankamani. 
administration of such an enzyme protein, in general, produces the corresponding antibody in the tissues, resulting in the anaphylactic shock or neutralization of drug effect, thus exploring novel serologically different L-asparaginase is a need of the hour (Jois et al., 2013).

L-asparaginase is an enzyme drug choice for acute lymphoblastic leukemia in children used in combination chemotherapy. Normal cells possess an enzyme L-asparagine synthase which satisfies for the requirement of the amino acid unlike in leukemic cells which have trivial or no $\mathrm{L}$ asparagine synthase. This deficit leads to the inhibition of DNA and RNA synthesis, blocking protein synthesis and destruction of cell function and cell death (Chande and Bhat, 2014). It is widely used in acute lymphoblastic leukemia, Hodgkin disease, acute myelocytic leukemia, acute myelomonocytic leukemia, chronic lymphocytic leukemia, lymphosarcoma treatment, and reticulosarcoma and melanosarcoma regimen. Apart from its therapeutic value, L-asparaginase also finds application in food industry. It has been found that L-asparaginase reduces the formation of carcinogenic acryl amides in deep fried potato recipes. Addition of asparaginase before baking or frying the food, results in conversion of asparagine into common amino acid, aspartic acid and ammonium. As a result, asparagine is unavailable to complete Maillard reaction, and thereby the formation of acryl amide is greatly lowered (Friedman, 2003).The present study aims to isolate, purify and characterize L-asparaginase from selected bacterial species.

Microbes residing in supreme habitat like alkaline or saline areas tend to express proteins with different characteristics than those inhabiting in the usual environment. Lonar Lake located in Buldhana district of Maharashtra appears to be one of the marvels of state and is considered to be the world's third largest crater formed due to a meteor impact. It is a saline soda lake with $\mathrm{pH}$ in the range of 10-12, serves as a distinctive habitat for isolation of halophiles and alkaliphilic organisms (Chande and Bhat, 2014). Studies on L-asparaginase producing isolate from Lonar Lake have not been reported very extensively and an attempt for the same is made in this study. The current study was aimed at exploring Gordonia terrae strain DSM43249 as a source of L-asparaginase.

\section{Materials and Methods:-}

Soil samples were collected in sterile containers from four side of Lonar lake $\left(19^{\circ} 58^{\prime} 36^{\prime \prime} \mathrm{N} 76^{\circ} 30^{\prime} 30^{\prime \prime} \mathrm{E}\right.$, Buldhana, Dist. Maharashtra, India) in the month of December. The $\mathrm{pH}$ of the lake was noted immediately at the site. Luhana's method (Luhana et al., 2013) was modified for carrying out production assay. It was grown at $37^{\circ} \mathrm{C}$ in shaker incubator and then transferred to Erlenmeyer flask for $72 \mathrm{~h}$ at $37^{\circ} \mathrm{C}$ in $\mathrm{M}-9$ media containing (per 1L distilled water): $\mathrm{Na}_{2} \mathrm{HPO}_{4}, 6.0 \mathrm{~g} ; \mathrm{KH}_{2} \mathrm{PO}_{4}, \quad 3.0 \mathrm{~g} ; \mathrm{NaCl}, \quad 0.5 \mathrm{~g} ; \mathrm{L}$-asparagine, $1 \% ; \mathrm{MgSO}_{4} .7 \mathrm{H}_{2} \mathrm{O} \quad 0.12 \mathrm{~g} ; \mathrm{CaCl}_{2} .2 \mathrm{H}_{2} \mathrm{O}$, $0.01 \mathrm{~g}$;peptone $0.6 \%$; yeast extract, $1 \%$; pH-7.0. At the end of incubation time, the samples were centrifuged at $10,000 \mathrm{rpm}$ for $15 \mathrm{~min}$, at $4^{\circ} \mathrm{C}$, and then cell free supernatant was used in further purification steps. All the assays were performed in triplicates.

\section{Enzyme Assay:-}

The enzyme was assayed by direct nesselerization method. One unit of L-asparaginase activity (IU) is defined as the amount of enzyme which liberates $1 \mu \mathrm{mol}$ of ammonia per min at $30^{\circ} \mathrm{C}$ and $\mathrm{pH} 7.4$ (Luhana et al., 2013).

\section{Estimation of Protein:-}

The protein contents were estimated by the method of Lowry using bovine serum albumin as the standard (Lowry, 1951).

\section{Purification of L-Asparaginase:-}

The activity of extracellular and intracellular crude enzyme was assayed. The extracellular concentration of the enzyme was significantly higher and hence it was used for further purification and characterization. The supernatant from the production media (crude enzyme) was subjected to serial ammonium sulfate precipitation $0 \%-40 \%, 40 \%$ $60 \%$ and $60 \%-80 \%$ and $80 \%-100 \%$ and enzyme assay for each fraction was carried out. Maximum activity was found in $60 \%$ saturation and hence this fraction was dialyzed against Tris buffer $(50 \mathrm{mM}, \mathrm{pH} 8.4)$ with three buffer changes at $4^{\circ} \mathrm{C}$ overnight. Gel filtration chromatography was done for dialyzed sample using Sephadex G-75 column $(1 \times 25 \mathrm{~m})$ equilibrated and eluted with $150 \mathrm{ml}$ Tris- $\mathrm{HCl}(50 \mathrm{mM}, \mathrm{pH} 8.4)$. The separated proteins were visualized by PAGE (Laemmli,1970) using Coomassie brilliant blue R-250 staining solution and the molecular weight of Lasparaginase was determined using standard molecular weight marker(medium range 97-14KDa;Sigma-Aldrich). 


\section{Characterization of L-Asparaginase:-}

The optimum conditions for the enzyme activity were determined by assaying at different temperatures $\left(10-45^{\circ} \mathrm{C}\right) \mathrm{pH}$ (4-10) (Sabbagh et al., 2013) and incubation time (10-60 minutes). The enzyme kinetics as measured by the Michaelis constant $(\mathrm{Km})$ is defined as the substrate concentration at half the maximum velocity, the rate of enzymatic reactions, by relating reaction rate to the concentration of a substrate. The Michaelis constant $(\mathrm{Km})$ value of the purified enzyme was estimated in a range of L-asparagine concentrations of 0.02M- 0.08 M. Line WeaverBurk plot analysis was carried out to calculate the apparent $\mathrm{Km}$ and Vmax value of purified L-asparaginase. The activity was determined in different concentrations of metal ion $\mathrm{MgCl}_{2}$ and metal ion chelator ethylenediamine tetra acetic acid (EDTA) in the concentration of $0.2-0.8 \mathrm{mg} / \mathrm{ml}$ in the reaction mixture (Mohapatra et al., 1995).

\section{Results and Discussion:-}

\section{Identification of Isolate:-}

The potential isolate was identified by $16 \mathrm{~S}$ rRNA sequencing method (Chromus Biotech Pvt.Ltd., Bangalore). The sequence was aligned with representative sequence. The isolate was found to be Gordonia sp KM067296.

Purification of L-asparaginase:-

The sequential multi steps purification procedures has been summarized in Table 1.

Table 1:- Enzyme activity after different stages of purification.

\begin{tabular}{|l|l|l|l|l|l|l|l|}
\hline Sample & $\begin{array}{l}\text { Volume } \\
(\mathbf{m l})\end{array}$ & $\begin{array}{l}\text { Enzyme } \\
\text { Activity } \\
(\mathbf{I U / m l})\end{array}$ & $\begin{array}{l}\text { Protein } \\
(\mathbf{m g} / \mathbf{m l})\end{array}$ & $\begin{array}{l}\text { Total } \\
\text { Activity(IU) }\end{array}$ & $\begin{array}{l}\text { Specific } \\
\text { Activity(IU/mg) }\end{array}$ & $\begin{array}{l}\text { Fold } \\
\text { Purification }\end{array}$ & $\begin{array}{l}\text { \% } \\
\text { yield }\end{array}$ \\
\hline Crude Extract & 200 & 54.61 & 19.5 & 10922 & 2.80 & 1 & 100 \\
\hline 80\% Dialysis & 8 & 32.77 & 5.5 & 262.16 & 5.95 & 2.12 & 2.4 \\
\hline Gel Filtration & 2 & 21.16 & 0.548 & 42.32 & 38.61 & 13.79 & 0.4 \\
\hline
\end{tabular}

Figure 1 shows the elution profile of the partially purified L-asparaginase from Sephadex G-75 (Sigma-Aldrich) column. A sharp distinctive peak of L-asparaginase activity, which fits with only one protein peak, was noticed. The most active fractions with specific activity $38.61 \mathrm{IU} / \mathrm{mg}$ and about 14 -fold purification were pooled together, concentrated and stored at $-20^{\circ} \mathrm{C}$.

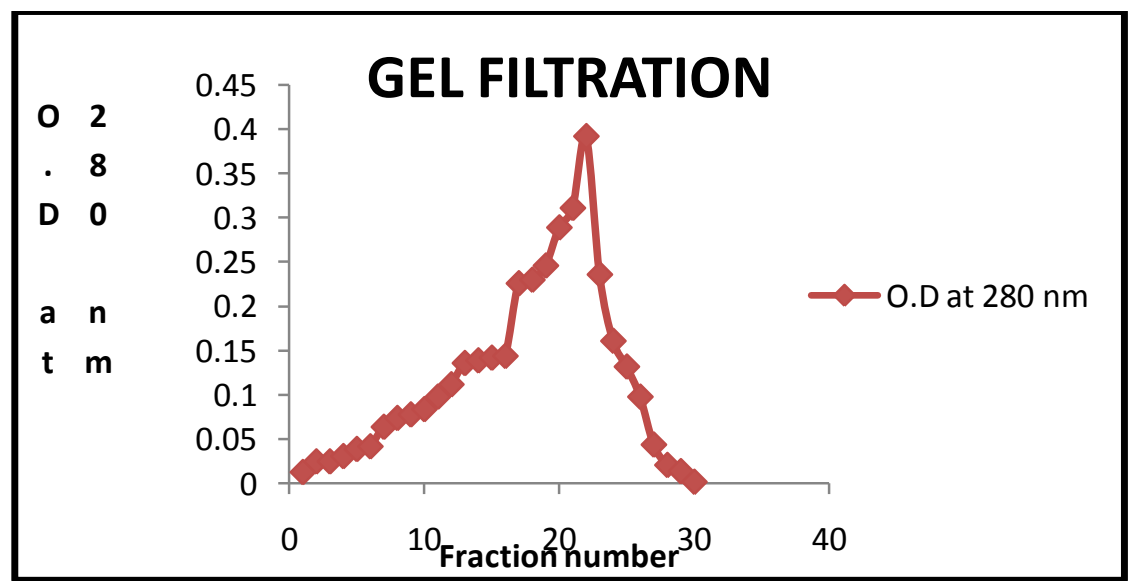

Figure 1:- Elution profile of Gel filtration chromatography of L-asparaginaseon Sephadex G-75.

Total protein was analyzed at $280 \mathrm{~nm}$. The fractions were assayed for enzyme activity. Fraction No.21 had highest specific activity of $38.61 \mathrm{IU} / \mathrm{mg}$ of protein

SDS PAGE revealed only a single distinctive protein band for the preparation of L-asparaginase with an apparent molecular weight of $12 \pm 2 \mathrm{kDa}$. In this respect, L-asparaginase purified from Pseudomonas MB-405, Thermus thermophilesand Escherichia coliwere with smaller MW values ranging from 33-34 kDa (Manna S, 1995) (Soares A.L, 2002).In figure2b, Lane 5 shows bands of various protein molecular weight markers, Lane 2 showing one band 
of purifiedL-asparaginase from Gordonia sp KM067296obtained throughsephadex G-75 chromatography separation with an apparent molecular weight of $12 \mathrm{KDa}$.

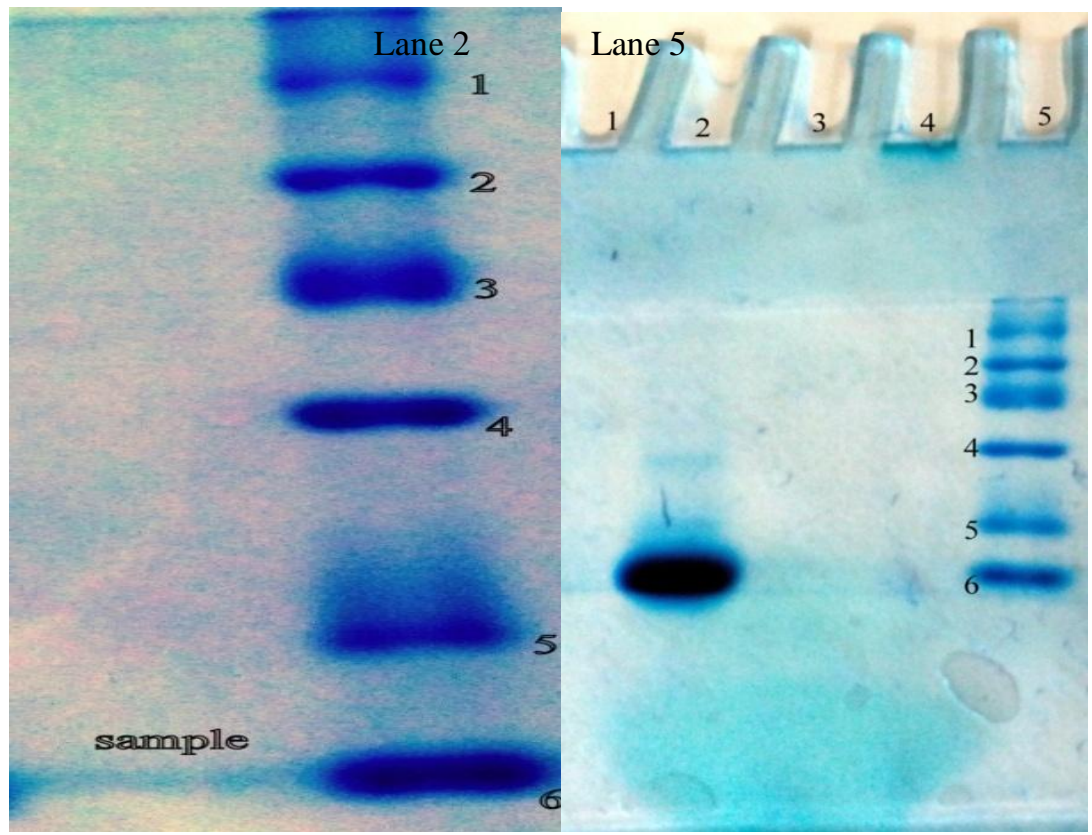

Figure 2a:-Separation of protein

Figure 2b:-Separation of protein bandsthrough SDS PAGE bands through Native PAGE

Characterization of Partially Purified L-asparaginase Enzyme

Effect of pH on enzyme activity:-

Results revealed that the $\mathrm{pH} 7.4$ was optimal for L-asparaginase from Gordonia terrae. These results coincide with that of Dhevagi and Poorani (2006) who reported the maximal L-asparaginase activity in Streptomyces spp. which was between $\mathrm{pH}$ 7.0-8.0, whereas $\mathrm{pH}$ 5.0-9.0 were reported earlier to be optimum for amidase activity (Ohshima et al., 1976).

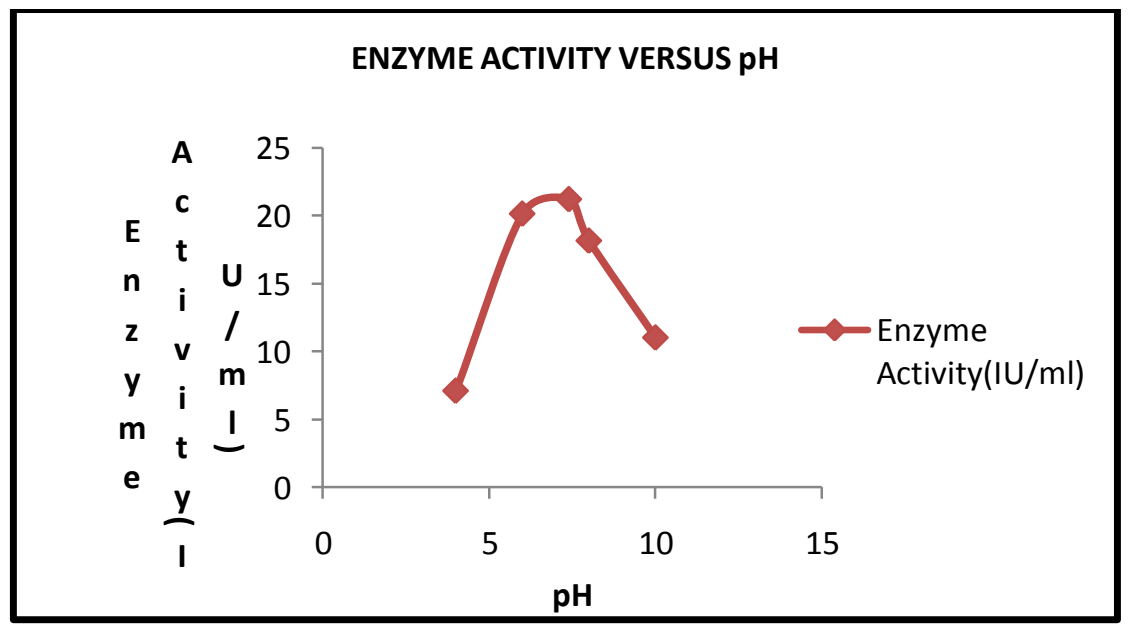

Figure 3:- L-asparaginase activity from Gordonia terrae in the range value of $\mathrm{pH}$ 4-10 in various buffers.

Effect of temperature on enzyme activity:-

The purified L-asparaginase was active at a range of temperature from $10^{\circ} \mathrm{C}$ to $40^{\circ} \mathrm{C}$ with an optimum at $37^{\circ} \mathrm{C}$, but its activity started decreasing as it approached $45^{\circ} \mathrm{C}$. These results were in agreement with a previous study where 
the temperature for optimum L-asparaginase activity obtained from Pseudomonas stutzeriMB- 405 was $37^{\circ} \mathrm{C}$. Lasparaginase from Erwinia spp. showed maximum activity at $35^{\circ} \mathrm{C}$ (Borkotaky and Bezbaruah, 2002).

\section{ENZYME ACTIVITY VERSUS TEMPERATURE}

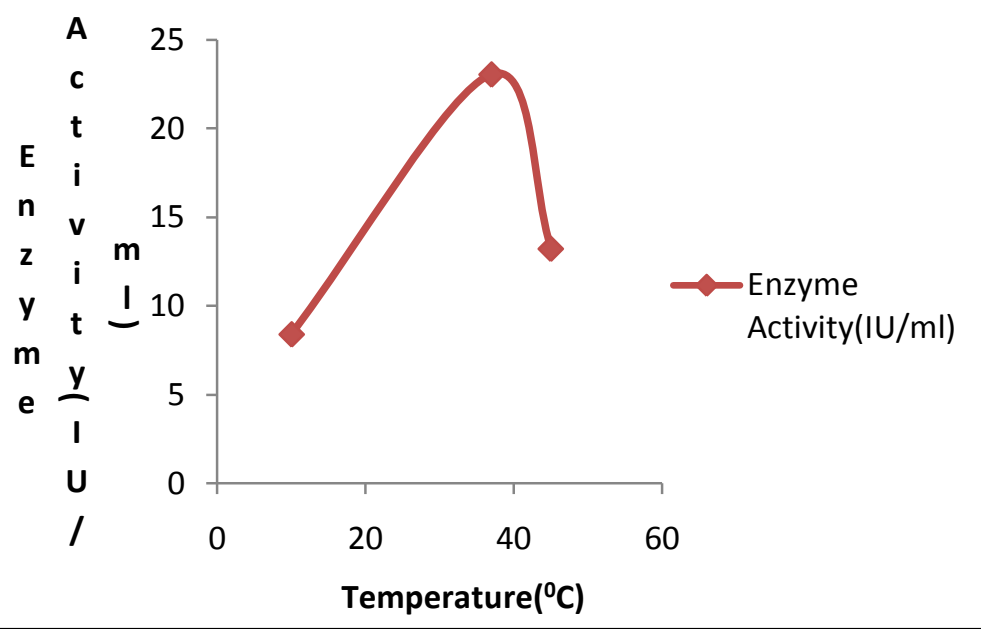

Figure 4:- Graph showing activity of L-asparaginase from Gordonia terrae at temperatures range of $10-60^{\circ} \mathrm{C}$ in Tris- $\mathrm{HCl}(\mathrm{pH}-7.4)$

\section{Effect of Incubation time on enzyme activity:-}

The L-asparaginase activity increased as the incubation time increased up to $45 \mathrm{~min}$, after which decrease in enzyme activity was seen wherein highest enzyme activity was observed at 30 mins. Similar results were recorded for Lasparaginase activity from chicken liver (Sayed E.M, 2011). The incubation of L-asparaginase purified from Ps.aeruginosa at $37^{\circ} \mathrm{C}$ for different time intervals showed that the activity reached its maximum at $30 \mathrm{~min}$ (Bessoumy et al., 2004).

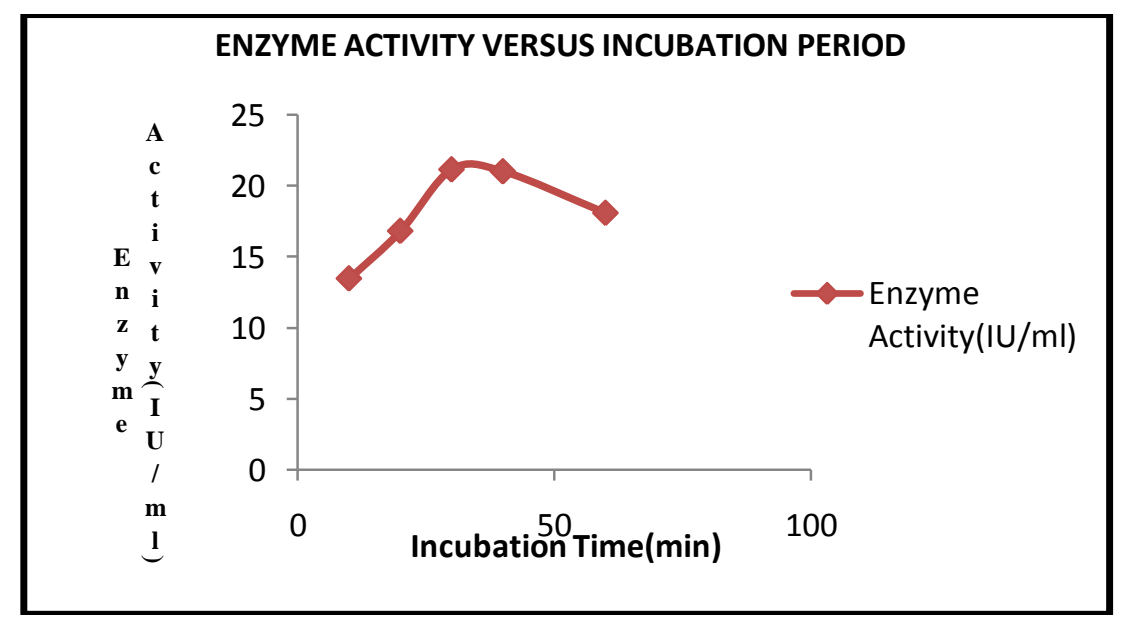

Figure 5:-Effect of incubation time on L-asparaginase activity from Gordonia terrae at different incubation period range of 10-60 minutes in Tris- $\mathrm{HCl}$ buffer ( $\mathrm{pH}-8.4)$.

Effect of metal ions on enzyme activity:-

Among the salts tested, considerable loss of activity was observed only with EDTA. The highest inhibition value was recorded with a concentration of $0.8 \mathrm{mg} / \mathrm{ml}$. There are reports that L-asparaginase extracted from Bacillus spp. was strongly inhibited by EDTA (Mohapatra et al., 1995). Addition of $\mathrm{MgCl}_{2}$ enhanced the enzyme activity to 
certain extent after which decrease in enzyme activity was seen. These results are in agreement with results reported for L-asparaginase from Erwinia caratovora (Warangkar and Khobragade, 2010).

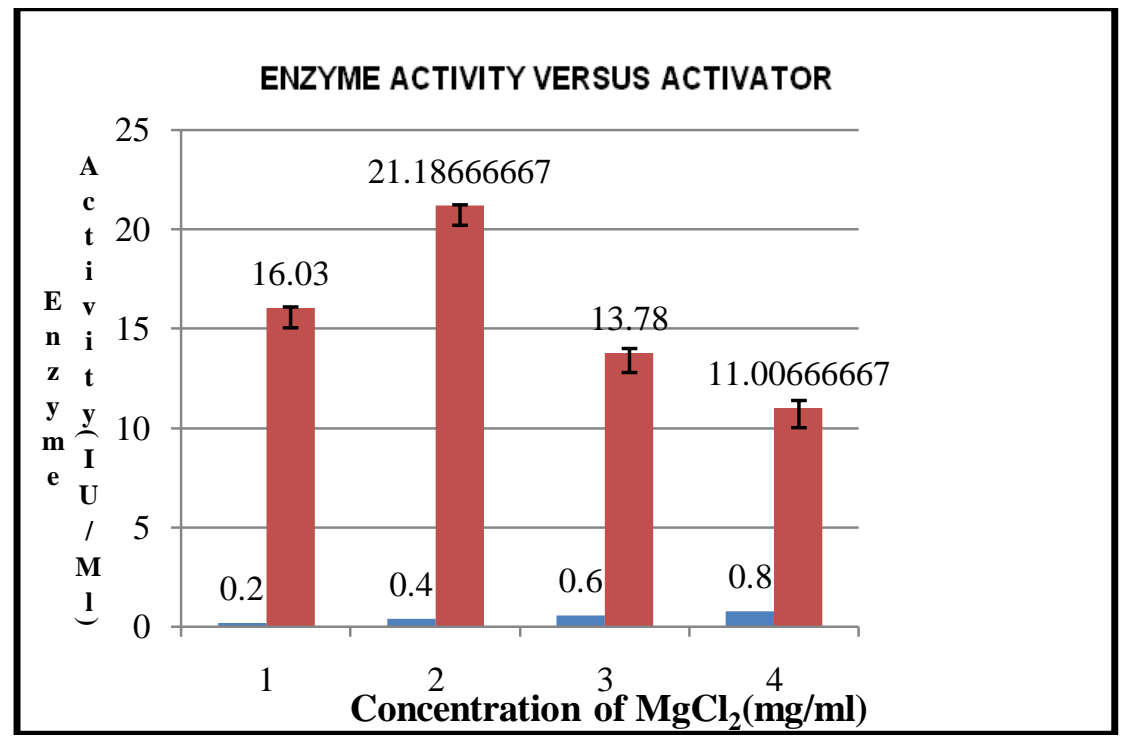

Figure 6:- Effect of activator L-asparaginase activity from Gordonia terrae at different concentration of activator $\left(\mathrm{MgCl}_{2}\right)$.

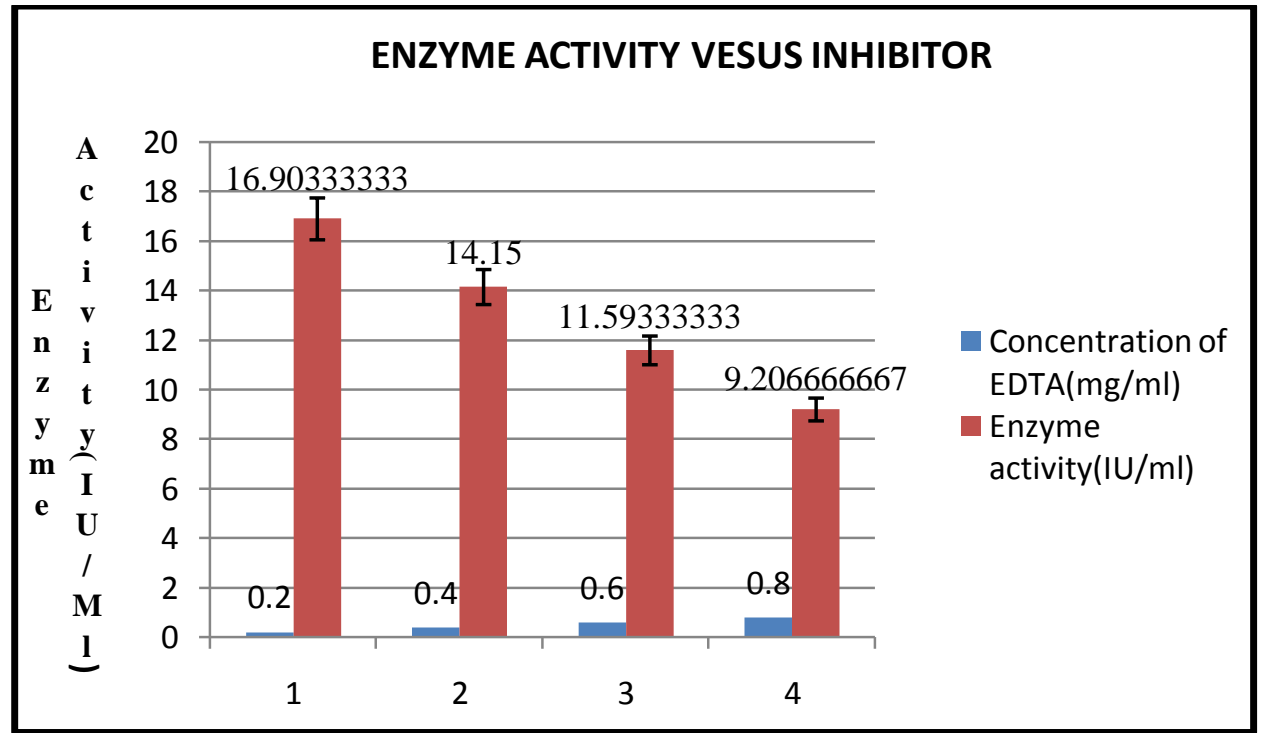

Figure 7:- Effect of Inhibitor on L-asparaginase activity from Gordonia terrae at different concentrations of inhibitor (EDTA).

Effect of substrate concentration on enzyme activity:-

A Line weaver Burk analysis showed a Km value of $0.061 \mathrm{mM}$ and Vmax of $0.57 \mathrm{IU}$. Higher Km values 6.6 and 7.0 $\mathrm{mM}$ for L-asparaginase from Lupinus arboreusand Lupinus angustifolius, respectively, has been reported (Chang and Farnden, 1981). On The other hand, a lower $\mathrm{Km}$ value $(0.058 \mathrm{mM})$ was obtained for L-asparaginase from Erwinia chrysanthemi 3937 (Kotzia and Labrau, 2007). 


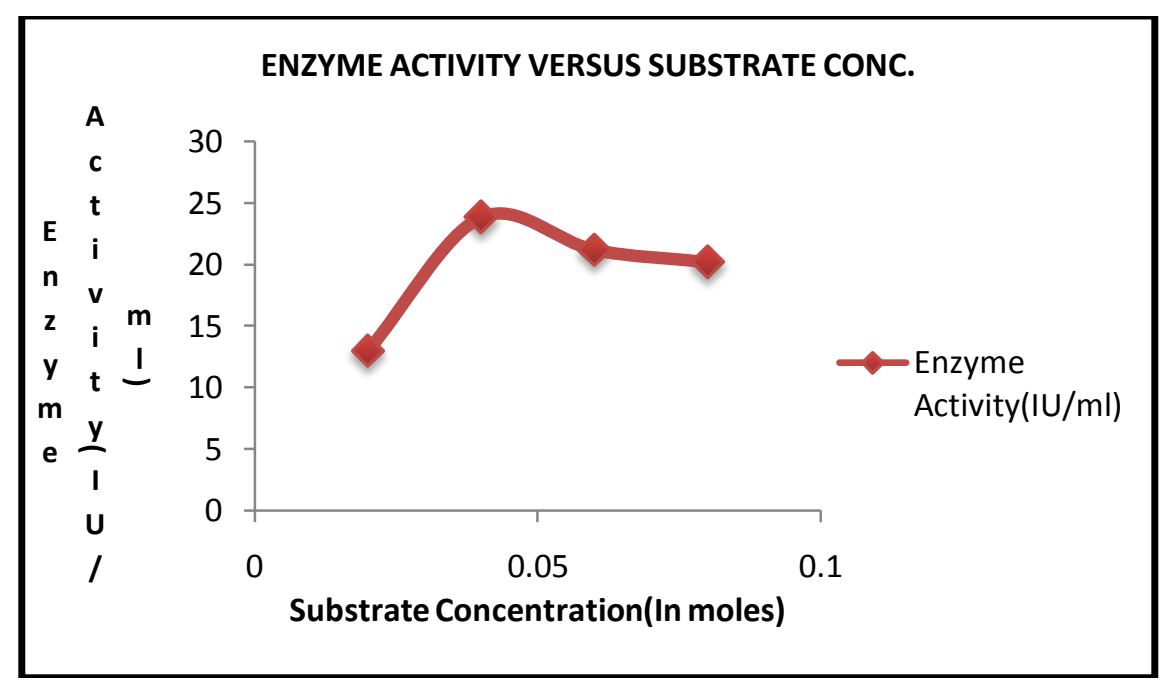

Figure 8:- Enzyme activity of L-asparaginase isolated from Gordonia terrae different substrate concentrations

\section{Conclusion:-}

The present study focused on production, partial purification and characterization of L-asparaginase from Gordonia terrae strainKM067296. The isolated Gordonia terrae has the ability to produce a significant amount of extracellular L-asparaginase. The present study indicates the isolated Gordonia terrae strain KM067296 used in this study will be a potential source for extracellular L-asparaginase enzyme. The kinetic parameters for optimal production of biologically active L-asparaginase have been ascertained. The high catalytic activity of the enzyme at physiological $\mathrm{pH}$ and temperature and its considerable stability over a wide range of $\mathrm{pH}$ and temperature makes it highly favorable to be exploited as a potent anticancer agent. Studies on the enzyme relating to purification and characterization would open new avenues in the application of the enzyme in the healthcare industry and for pharmaceutical, therapeutic, commercial purposes.

\section{References:-}

1. Aljewari, H.S, Nadar, M., Alfaisal, A. and Weerapreeyakul, N. (2010):High efficiency selectivity against cancer cell line of purified L-asparaginase from pathogenic Escherichia coli. World Academy of Science Engineering and Technology, 41: 355-360.

2. Anese, M., Quarta, B., Frias, J.(2011): Modelling the effect of asparaginase in reducing acrylamide formation in biscuits. Food Chemistry,126(2)(15): 435-440.

3. Chande,A. and Bhat, M. (2014): Isolation and Characterization of L-asparginase producing isolate from Lonar Lake, Buldhana District, MS, India. Research Journal of Recent Sciences, 3: 38-41.

4. Bessoumy, A.A., Sarhan, M. and Mansour, J. (2004): Production, isolation and purification of Lasparaginase from Pseudomonas aeruginosa 50071 using solid state fermentation. J. Biochem. Mol Bio., 37:387-393.

5. Borkotaky, B. and Bezbaruah, R. (2002):Production and properties of asparaginase from new Erwinia spp. Folia Microbiol., 47:473-476.

6. Chang, K. and Farnden, K. (1981):Purification and properties of L-asparaginase from Lupinus arboreus and Lupinus angustifolius. Arch Biochem Biophy., 208:49-58.

7. Dhevagi, P. andPoorani, E. (2006): Isolation and characterization of L-asparaginase from marine Actinomycetes. Ind. J. Biotechnol., 5:541-520.

8. Eishafei, A.A., Hasan, M.Abouzeid, M., Mahmaud, M. and Elghonemy, D. (2012): Purification, Characterization and Antitumor Activity of L-asparaginase from Penicillium brevicompactum NRC 829. British Microbiology Research Journal, 2(3): 158-174.

9. Friedman, M.(2003):Chemistry, biochemistry and safety of acrylamide, A review. J. Agric. Food Chem.,51: 4504-4526.

10. Jois, S., Chandru, S., Chavan, A., Ramchandra, Y. and Rai, P.(2013): Study on production, purification and characterization of L-asparaginase from Eschrichia coli and Pseudomonas aeruginosa. IJPCBS.,3(3):565-570. 
11. Kotzia, G.A. and Labrau, N. (2007): L-asparaginase from Erinia chrysanthemi 3937: cloning, expression and characterization. J. Biotechnol., 127: 657-669.

12. Kumar, Kand Verma, N. (2012):The various sources and applications of L-asparaginase. Asian Journal of Biochemical and Pharmaceutical Research, 2:197-205.

13. Laemmli, U.K. (1970): Cleavage of structural proteins during assembly of head of bacteriophage T4. Nature , 227: 680-685.

14. Lowry, O.H. (1951):Protein measurement by Folin phenol reagent. Journal of Biological Chemistry, 193:266275.

15. Luhana, K.K., Dave, A. and Patel, K. (2013):Study of anti leukemic enzyme L-asparaginase from halophilic bacterial isolates of Bet Dwarka Island. International journal of Chemtech application, 2: 81-93.

16. Manna, S., Sinha, A., Sadhukhan, R. and Chakrabarty, S.L. (1995):Purification, characterization and antitumor activity of L-asparaginase isolated form Pseudomonas stutzeri MB-405. Curr. Microbiol., 30:291298.

17. Mohapatra, B.R., Sani, R.K. and Banerjee,U.C. (1995): Characterization of L-asparaginase from Bacillus spp. isolated from an intertial marine alga (Sargassum spp.). Lett. Appl. Microbiol., 21:380-383.

18. Ohshima, M., Yamamoto, T. and Soda, K. (1976). Further characerization of gultaminase isoenzymes from Pseudomonas aeruginosa. AgriBiologi Chem., 40:2251-2255.

19. Sabbagh, S.M., El-Batonony, N. and Salem, T. (2013): L-asparaginase produced by Streptomyces strain isolated from Egyptian soil: Purification, characterization and evaluation of its anti-tumor activity. Africian journal of Microbiology Research, 7(50): 5677-5686.

20. Sayed, E.,El-Sayed, M., El-Sayed, S.T., Shausha, W.G., Shausha, G., Abeer., Shehata, N., Sheema. and Hanafy, S. (2011): Purification, characterization and antitumor activity of L-asparaginase from chicken liver. $J$. Am. Sci., 7: 439-449.

21. Soares, A.L., Guimarães, G., Polakiewicz, B., de Moares Pitambo, R.N. and Abrahão-Neto, J. (2002): Effect of polyethylene glycol attachment on physicochemical and biological stability of Escherichia coli L-asparaginase. Int.J. Pharma., 237:163-170.

22. Warangkar, S.C. and Khobragade, C. (2010): Purification, characterization and effect of thiol compounds on activity of Erwinia carotovora L-asparaginase. Enz. Res., 1: 1-10. 